Institute of $\mathbf{F}_{\text {ood and }} \mathbf{A}_{\text {gricultural }} \mathbf{S}_{\text {ciences }}$

\title{
Nematode Management on Bedding Plants ${ }^{1}$
}

\author{
William T. Crow ${ }^{2}$
}

Florida means the "land of flowers." Surely, one of the things that Florida is known for is the beauty of our vegetation. Due to our idyllic environment, color can abound in our landscapes year round.

Unfortunately, plants are not the only organisms that enjoy our mild climate. Due to warm temperatures, sandy soil, and humidity, Florida has more than its fair share of pests and pathogens that attack bedding plants. Plant-parasitic nematodes (Figure 1) can be among the most damaging and hard-to-control of these organisms.

\section{What are Nematodes?}

Nematodes are unsegmented roundworms, different from earthworms and other familiar worms that are segmented (annelids) or in some cases flattened and slimy (flatworms). Many kinds of nematodes are found in the soil of any landscape. Most are beneficial, feeding on bacteria, fungi, or other microscopic organisms, and some may be used as biological control organisms to help manage important insect pests (http://edis.ifas.ufl.edu/IN468). There also are nematodes that feed on plants, called plant-parasitic nematodes (Figure 1).

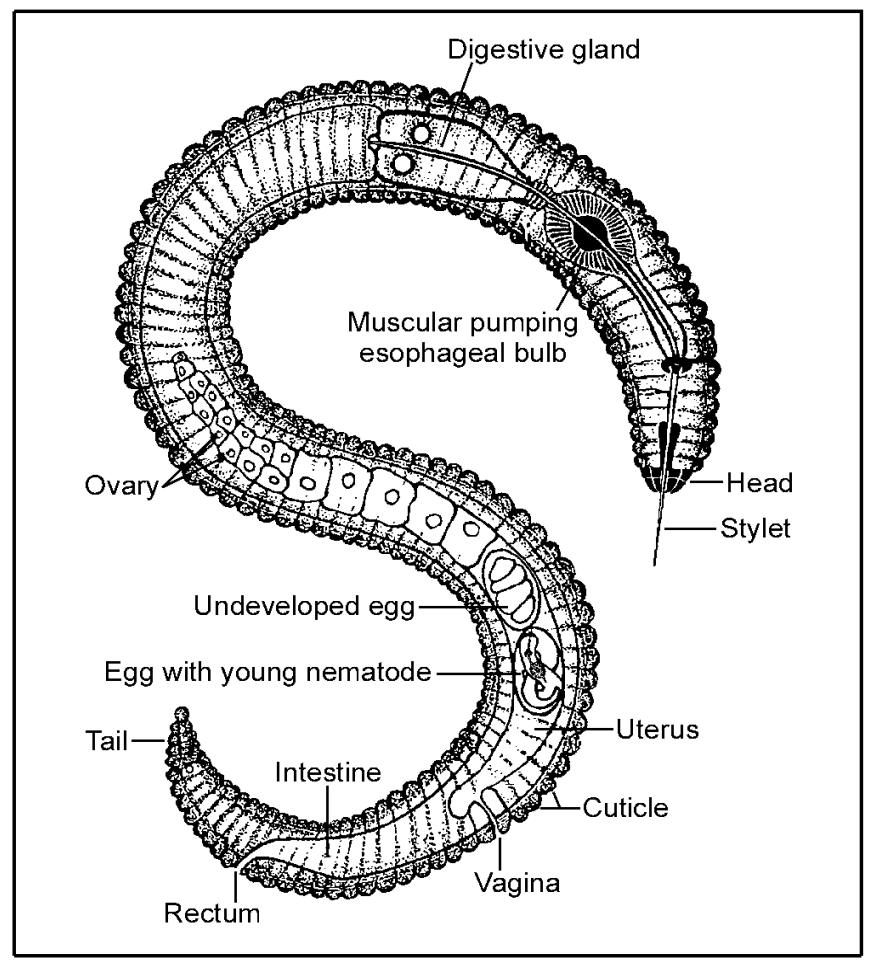

Figure 1.

Plant-parasitic nematodes are very small and most can only be seen using a microscope (Figure 2). All plant-parasitic nematodes have a stylet or mouth-spear that is similar in structure and function

1. This document is ENY-052, one of a series of the Entomology and Nematology Department, Florida Cooperative Extension Service, Institute of Food and Agricultural Sciences, University of Florida, Gainesville, FL. Publication date: April 2003. For more publications related to horticulture/agriculture, please visit the EDIS Website at http://edis.ifas.ufl.edu/.

2. William T. Crow, assistant professor, Entomology and Nematology Department, Cooperative Extension Service, Institute of Food and Agricultural Sciences, University of Florida, Gainesville, 32611.

The use of trade names in this publication is solely for the purpose of providing specific information. UF/IFAS does not guarantee or warranty the products named, and references to them in this publication does not signify our approval to the exclusion of other products of suitable composition. All chemicals should be used in accordance with directions on the manufacturer's label. Use pesticides safely. Read and follow directions on the manufacturer's label.

The Institute of Food and Agricultural Sciences is an equal opportunity/affirmative action employer authorized to provide research, educational information and other services only to individuals and institutions that function without regard to race, color, sex, age, handicap, or national origin. For information on obtaining other extension publications, contact your county Cooperative Extension Service office. Florida Cooperative Extension Service/Institute of Food and Agricultural Sciences/University of Florida/Christine Taylor Waddill, Dean. 
to a hypodermic needle (Figure 3 ). The nematode uses its stylet to puncture plant cells and then inject digestive juices and ingest plant fluids through it. Most of the plant-parasitic nematodes that are important on ornamental plants in Florida feed on roots. Some plant-parasitic nematodes remain in the soil and feed by inserting only their stylet into the root; these are called ectoparasitic nematodes (Figure 4). Nematodes that enter the plant with part or all of their body are called endoparasites. Some endoparasites continually burrow around inside the root; these are called migratory endoparasites (Figure 5). Other endoparasites, called sedentary endoparasites, establish permanent feeding sites inside the root. Once a feeding site is established the nematode no longer moves. The sedentary endoparasite's body changes shape and is usually swollen (Figure 6).

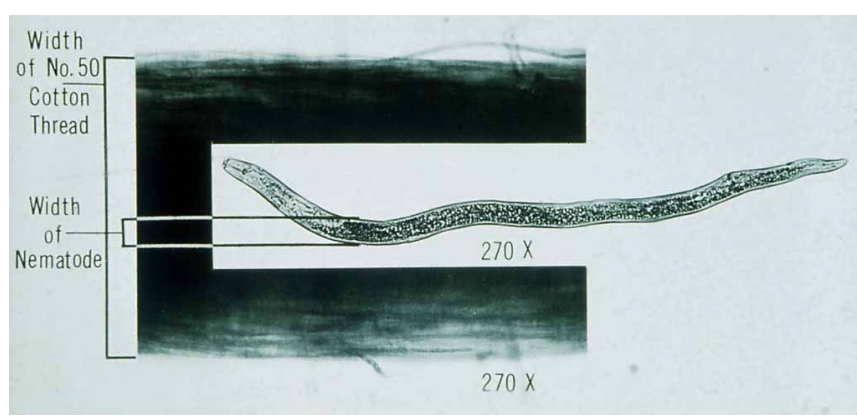

Figure 2. Size comparison of a typical plant-parasitic nematode to a cotton thread.

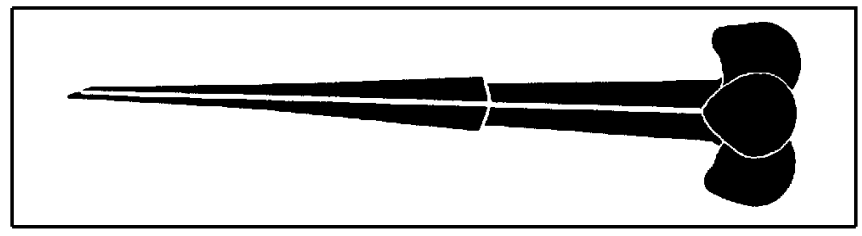

Figure 3. A typical plant-parasitic nematode stylet resembles a hypodermic needle.

\section{How Do Nematodes Damage Plants?}

As plant-parasitic nematodes feed, they damage the root system and reduce the ability of the plant to obtain water and nutrients from the soil. When nematode numbers get high, and/or when environmental stresses occur, aboveground symptoms may become evident. Aboveground nematode symptoms often resemble nutrient deficiencies or drought stress. Symptoms include yellowing, wilting, thinning and stunting. These symptoms occur because

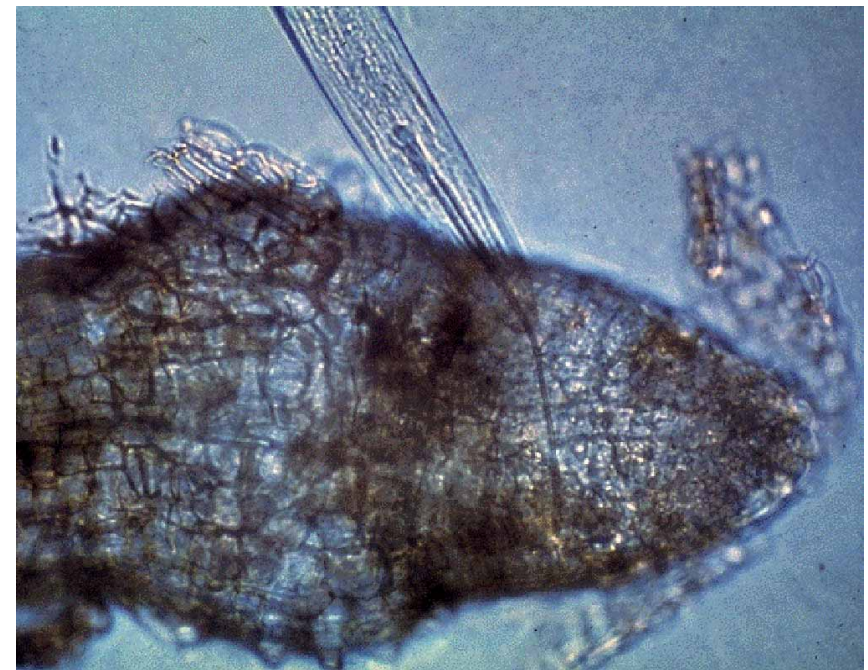

Figure 4. An ectoparasitic nemtode feeding by inserting its stylet into a root tip.

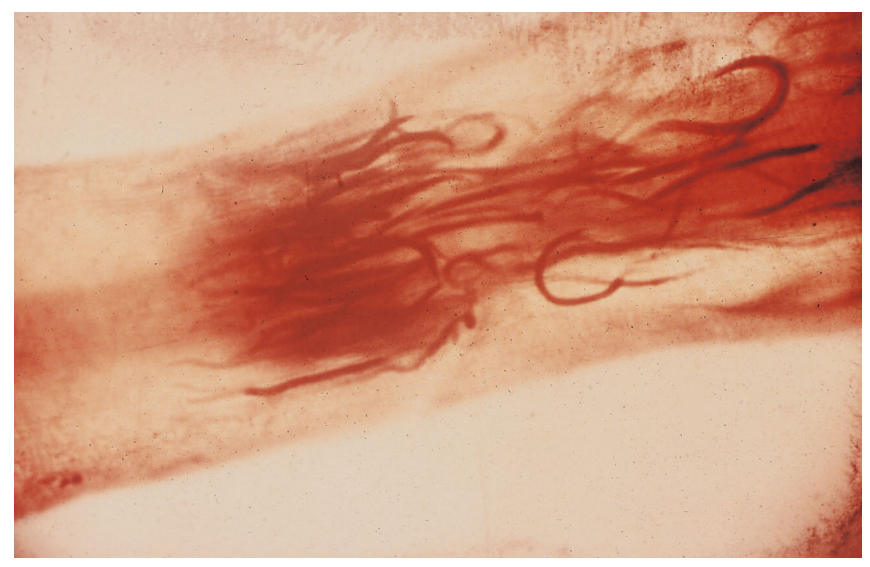

Figure 5. Endoparasitic nematodes burrowing within a root.

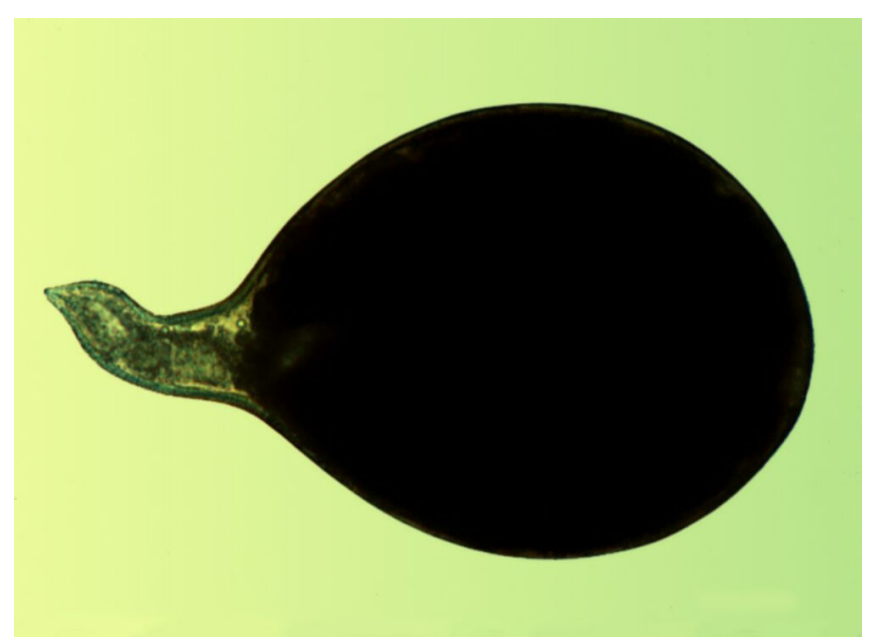

Figure 6. An adult female cyst nematode. This is a sedentary endoparasite.

the damaged roots cannot take up water and nutrients from the soil properly. If plants are planted into beds that already have high population densities of plant parasitic nematodes, they may remain small and 
never grow at all. Eventually these plants may slowly die. Nematode damage usually occurs in localized areas that may enlarge slowly over time. Be aware that similar conditions may be caused by other factors such as localized soil conditions, fungal diseases, or insects.

\section{Root-knot Nematodes}

Root-knot nematodes are the most well known of the plant-parasitic nematodes. These are sedentary endoparasites. Four species are common in Florida on bedding plants, Meloidogyne incognita, M. arenaria, $M$. javanica, and $M$. mayaguensis. The nematodes inject hormones into the roots that cause knots or galls to form (Figure 7). These galls are the only nematode symptoms that are easily recognized. Root-knot nematodes cause extensive damage and changes in the root system. These changes allow fungi and bacteria to get into the plant. Some of these organisms cause rotting of the root systems, while others cause vascular wilts. Sometimes the damage caused by the nematodes and the other organisms together is worse than that caused by both organisms separately.

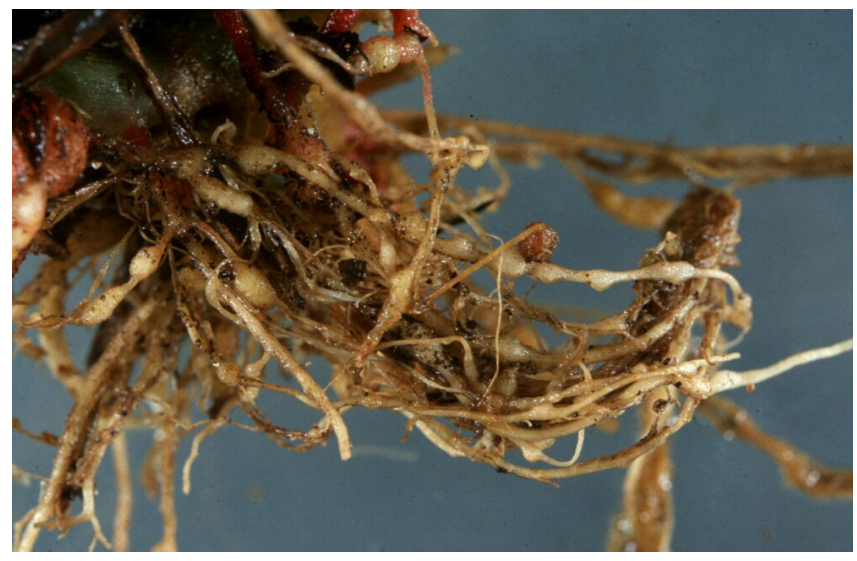

Figure 7. Root-knot nematode galls on impatiens roots.

Root-knot nematodes are one of the most destructive plant-parasites. High infestations can kill many types of bedding plants. Tables 1 and 2 list some of the annual bedding plants common in Florida, and their susceptibility to several species of root-knot nematodes. This is not an exhaustive list; the majority of plants may be affected by root-knot occasionally. Different cultivars of the same plant species may react differently to the nematodes. Table 3 shows the reactions of several different cultivars of
Vinca (periwinkle), and Salvia to several species of root-knot nematodes.

\section{Ectoparasites}

Several ectoparasitic nematodes are capable of causing damage to bedding plants in Florida. The most destructive of these are the sting, awl, and stubby-root nematodes. Feeding by these nematodes usually cause roots to be stunted or stubby looking (Figure 8). Sting nematodes are found in sandy soil and are common throughout much of Florida. Awl nematodes usually are found in wet habitats such as near ditches, ponds, or poorly drained areas. Several stubby-root species are found in Florida, one or more can usually be found in most Florida habitats. Other ectoparasitic nematodes that may parasitize bedding plants are lance, spiral, stunt, ring, sheath, sheathoid, dagger, and needle nematodes.

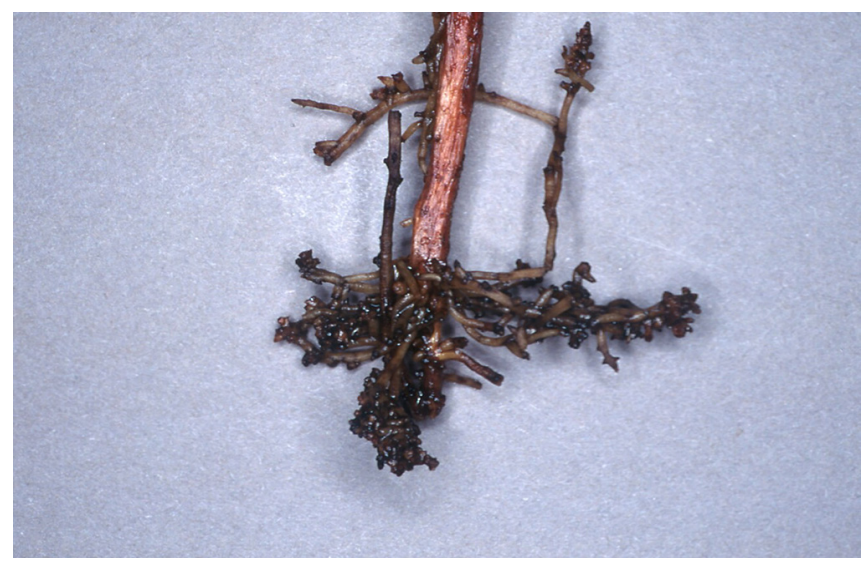

Figure 8. Some nematodes cause an abbreviated or "stubby" root system.

\section{How Do I Know if Nematodes are a Problem?}

With any plant problem, having an accurate diagnosis is important to address the problem and to avoid wasting effort and unnecessary pesticide applications. Generally, nematode symptoms are identical to other disorders so visual inspection is not enough. The only reliable way to determine if plant-parasitic nematodes are involved in a plant problem is by having a nematode assay conducted by a professional nematode diagnostic lab. The University of Florida Nematode Assay Lab will evaluate nematode samples for a cost of $\$ 12.00$ each. Nematode sample kits (Figure 9) containing 
everything needed to collect and submit a sample, along with instructions, are available at your local county Cooperative Extension office.

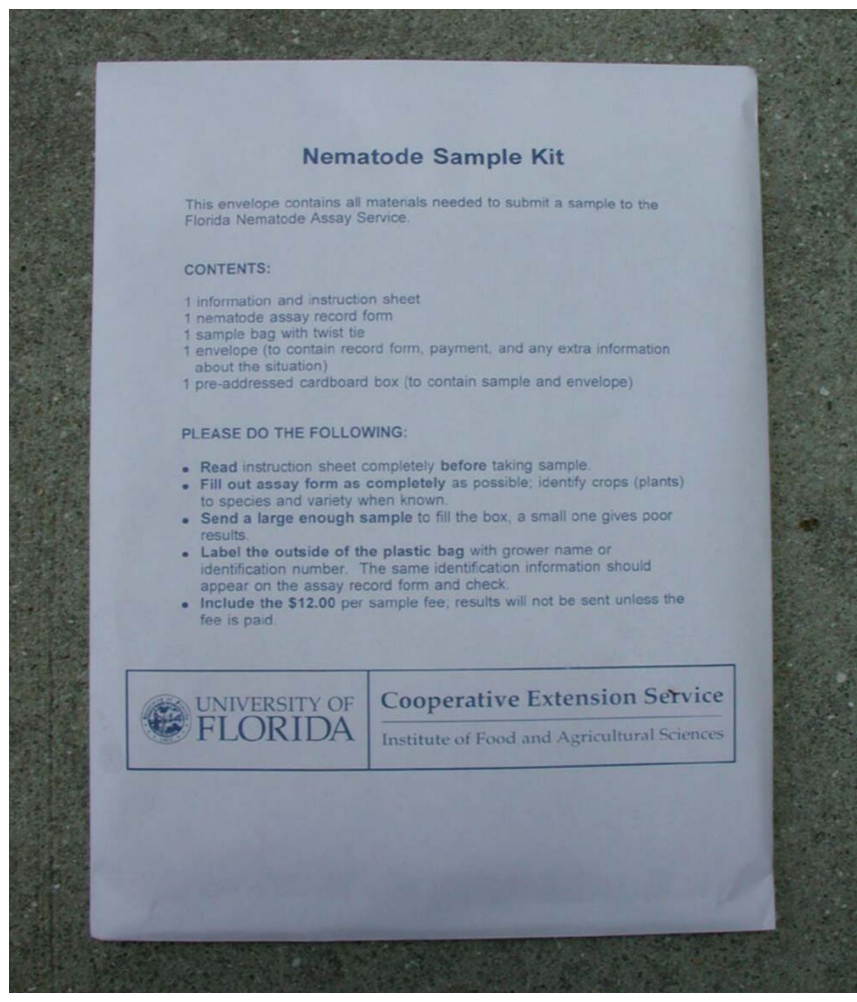

Figure 9. The University of Florida Nematode Assay Kit.

Nematode analysis is a separate procedure and requires different sampling guidelines than those required for soil analysis or plant disease samples. Do not send samples in soil test bags! The addresses are different and, more importantly, the soil testing bags are designed to dry soil out. Drying invalidates the results of a nematode assay. The accuracy of the diagnosis depends on the quality of the sample that you submit. If you are taking a sample for submission to another lab, or if you are submitting a sample to the University of Florida lab without using our sample kits, following the guidelines below will help insure an accurate diagnosis.

\section{Sampling}

\section{Before planting: Collect soil from 8 to 12} locations in a planting bed. Samples should be taken 8 to 10 inches deep. About a handful of soil from each location is adequate. Combine all the soil into a single plastic bag. The total volume of soil from the samples should be about 1 pint. Samples may be taken with a shovel, trowel or other device. If using a shovel you can put part of the soil from 8 to 12 shovels full into a bucket. Thoroughly mix the soil in the bucket then take out a pint to submit for analysis.

After planting: Often a nematode assay is needed to determine if nematodes are causing a plant to get sick. For this type of sample both soil and roots are required! Dig soil and roots from around the drip line of the plant. Sample depth depends on the size of the plant. For most bedding plants 6 inches deep is adequate. Do not include the top 1 inch of soil. If multiple plants are affected, collect some soil and roots from several plants. Place the soil and roots together in the same plastic bag. A minimum of 1 pint of soil and 1 to 2 cups of roots are required. For small bedding plants, entire plants with the soil around their roots can be submitted.

\section{Handling}

1) If submitting more than one sample make sure that the outside of each bag is labeled with a permanent marker. You also can write on masking tape stuck to the bag. Do not put paper labels inside of bags, they will decompose and be illegible. If submitting several samples together wrap each in newspaper so that the labeling doesn't wear off.

2) Seal the plastic bags to keep the sample moist. Dried out samples are no good for nematode diagnosis. Self-sealing bags often come open in the mail. If using a self-sealing bag tape the seal shut.

3) Keep samples out of direct sunlight or heat. Heat and ultraviolet light kill nematodes. Even a few minutes on the dashboard or in the back of a pickup can invalidate assay results. If you are storing the sample for more than a day it is best to keep it refrigerated, but not frozen.

4) Handle the sample gently and pack it well. Nematodes are between soil particles. So, the more the soil gets banged around the more the nematodes may get destroyed.

5) Fill out the information on the nematode assay form (http://edis.ifas.ufl.edu/pdffiles/SR/SR02300.pdf). In order to make a diagnosis we need to know as much as possible about the plant or plants in question. 
Make sure that the identification on the form matches the identification on the sample bag.

\section{Submitting the Sample}

1) There is a $\$ 12$ fee for each nematode sample. Place a check or money order payable to the "Florida Nematode Assay Service" into an envelope. Do not send cash.

2) Put the sample, assay form, and payment envelope into box. Seal the box with gummed tape.

3) Mail, ship, or deliver the samples to the Nematode Assay Lab as soon as possible. The mailing address is: Nematode Assay Lab, Building 78 Mowry Rd., Gainesville, FL 32611.

\section{What Can I Do About Nematodes?}

\section{Chemicals}

There are no effective chemical treatments labeled for use on bedding plants at this time.

\section{Resistance and Tolerance}

Plants on which a particular nematode cannot reproduce are termed resistant to that nematode. Plants that can be fed on by the nematode but are not damaged are termed tolerant. While a great deal of work has gone into identifying nematode resistant agronomic and vegetable crops, little work has been done with bedding plants. This is an area of research we are currently exploring at the University of Florida. For now, the plants identified as susceptible in Tables 1 and 2 should be avoided in areas where root-knot nematodes are known to occur. If growing resistant plants with plans to plant susceptible plants later, it is important to keep the area as weed free as possible. If weeds are allowed to grow, the nematodes may maintain their populations by feeding on the weeds.

Marigolds often are promoted as nematode resistant. Table 4 lists the susceptibility of a number of species and cultivars of marigold to different species of root-knot nematodes. Different types of marigolds are resistant to different species of root-knot nematodes. Few cultivars are resistant to all of them. Therefore, while marigolds may grow very well in soil infested by root-knot nematodes, there is always a possibility of nematode damage occurring.

Several cultivars of salvia appear to be resistant to at least two of the root-knot species common in Florida (Table 3). These cultivars may be useful for planting in soil infested with root-knot nematodes. Vinca (Periwinkle) is a plant that does not support populations of certain root-knot nematodes even though it may have galling (Table 3). So, once the plant gets past the initial galling, it should do well.

\section{Solarization}

Solarization is a process of using heat from the sun to kill nematodes and other pests. The soil should be worked with a hoe or rototiller to break up clods. Remove all sticks, roots, and clumps. The soil should be moist, but not wet. Cover the soil with a clear plastic tarp and bury the edges of the plastic. Leave the plastic on the soil for at least 4 to 6 weeks. Do not remove the plastic until you are ready to plant.

Sunlight goes through the clear plastic and heats the soil underneath. The plastic then holds in the heat so it penetrates the soil. Long-term exposure to high temperature kills nematodes, as well as many weeds, fungi, and insect pests. The disinfested zone is usually 6 to 8 inches deep. Do not till or mix the soil after solarization, since that may reinfest the soil you just solarized with nematodes from below the treated zone. Because it depends on sunlight and heat, solarization works best during the summer months. It does not work well in areas that get shade. So, only solarize planting beds in full sun.

The benefits of solarization may be enhanced by using a second layer of plastic suspended by wire hoops. An air gap is created between the two layers of plastic giving extra insulation. Also, weeds that penetrate the first layer may then be killed by heat trapped between the plastic layers.

\section{Organic Amendments}

Organic amendments can be added to soil as compost, manure, green manure, or other materials. Organic matter can help prevent nematode damage in several ways. The organic matter increases the ability of the soil to hold water and nutrients, and improve 
soil structure. This makes a better environment for most plants and can help the plants survive in spite of the nematodes. Organic amendments can also increase natural enemies of nematodes that suppress the nematode populations. Some organic amendments can release chemicals or gases that are toxic to the nematodes.

There are several "organic" nematode management products for sale. Researchers with the University of Florida have worked with a number of these, but probably not all of them. In the majority of cases, these products work no better than adding any other, less expensive, organic material.

For more detailed information on these topics see "Soil organic matter, green manures, and cover crops for nematode management" online at http://edis.ifas.ufl.edu/VH037 or at your county Cooperative Extension Service office.

\section{Planting}

Nematode activity slows as soil temperatures drop. Therefore, annual plants grown in cooler months do not suffer as much from nematodes as those grown in warmer months. Become familiar with the temperature requirements of the plant and grow as early as possible in the Spring or as late as possible in the Fall.

Older transplants generally are more resistant to nematodes than younger transplants. So, older transplants should be used in nematode infested soil. Inspect the roots of all landscape plants before purchase for root-knot galls or other root-related problems. Occasionally nematodes can be introduced with contaminated plants.

\section{Sanitation}

Roots left in the soil can continue to live and support nematode reproduction. Root-knot nematode eggs are attached to roots and will continue to hatch even after the plant appears to be dead. Therefore, as soon as it is clear that a plant is dying it is best to pull it up. Make sure to dig up as many roots as possible and destroy them.

Always be aware that when soil is moved pathogens can be moved with it. After digging up sick plants make sure that any shovels or other equipment are thoroughly cleaned after use. It is best to rinse the equipment with a solution of 1 part bleach in 9 parts water to disinfest the surface. This should remove any plant-parasitic nematodes or other pathogens in adhering soil.

\section{Remove Infested Soil}

In annual planting beds it is sometimes practical to replace infested soil and start over. Nematodes may reinfest the soil later, but by then the plants should have a good root system established. The better developed the root system is, the more tolerant the plant will be to nematodes.

Reinfestation can be slowed by using root barrier fabric. This fabric is laid down and then the new soil is placed on top. The barrier will prevent plant roots from growing into the infested soil below. It also may prevent infested roots from outside growing into the non-infested soil.

\section{Container Growing}

Growing plants in containers off the ground can avoid having to deal with nematode problems. Make sure you inspect the plants for root-knot galls. You dont want to introduce a problem. Also use clean potting media. Do not mix potting media with native soil or you might contaminate it.

\section{Summary}

Following the recommendations listed in this document can help avoid or reduce problems with plant-parasitic nematodes in the landscape. However, there are no guarantees of success. County and state faculty with the University of Florida are continually exploring new nematode management options. This document will be updated yearly to make the most recent data available to you. If you are reading an older version of this document you are encouraged to look at the current version on-line at http://edis.ifas.ufl.edu/ or at your county Cooperative Extension Service office. 
Table 1. Root galling and reproduction of root-knot nematodes on twelve annual ornamental species ${ }^{1}$. Columns show reactions of each plant species to a root-knot nematode population in work done by C. C. Goff in the 1930's (more plants are listed in Table 2), common root-knot nematode (Meloidogyne incognita), javanese root-knot nematode (M. javanica), and "peanut" root-knot nematode (M. arenaria).

\begin{tabular}{|c|c|c|c|c|c|c|c|}
\hline \multirow{2}{*}{$\begin{array}{l}\text { Bedding Plants -- } \\
\text { Common Names }\end{array}$} & \multirow{2}{*}{$\begin{array}{c}\text { Goff's } \\
\text { Rating }\end{array}$} & \multicolumn{2}{|c|}{ Meloidogyne incognita } & \multicolumn{2}{|c|}{ Meloidogyne javanica } & \multicolumn{2}{|c|}{ Meloidogyne arenaria } \\
\hline & & Galling $^{2}$ & Eggs $^{2}$ & Galling $^{2}$ & Eggs $^{2}$ & Galling $^{2}$ & Eggs $^{2}$ \\
\hline Ageratum 'Blue Mink' & --- & 0 & 0 & 0 & 0 & 0 & 0 \\
\hline Alyssum 'Rosie O'Day' & $\mathrm{VL}$ & --- & --- & 0 & 0 & 0 & $\mathrm{VL}$ \\
\hline Celosia 'Century Mix' & $\mathrm{VH}$ & $M$ & $\mathrm{H}$ & L & $M$ & $\mathrm{H}$ & $\mathrm{H}$ \\
\hline Coleus 'Rainbow' & $\mathrm{H}$ & $\mathrm{VL}$ & $L$ & $M$ & $L$ & $M$ & $\mathrm{VH}$ \\
\hline Dianthus 'Baby Doll Mix' & $L$ & $L$ & 0 & $\mathrm{VL}$ & $\mathrm{VL}$ & $\mathrm{VL}$ & $\mathrm{VL}$ \\
\hline Marigold 'Dwarf Primrose' & 0 & 0 & 0 & 0 & 0 & $\mathrm{VL}$ & $\mathrm{VL}$ \\
\hline Periwinkle 'Little Bright Eye' & VL & 0 & 0 & $\mathrm{VL}$ & $\mathrm{VL}$ & $\mathrm{L}$ & $\mathrm{VL}$ \\
\hline Petunia 'Dwarf Bedding' & $L$ & $\mathrm{~L}$ & $\mathrm{VL}$ & $\mathrm{VL}$ & $M$ & $\mathrm{~L}$ & $L$ \\
\hline Salvia 'Bonfire' & $\mathrm{VL}$ & 0 & 0 & $\mathrm{VL}$ & $\mathrm{VL}$ & --- & --- \\
\hline Snapdragon 'First Ladies' & $\mathrm{H}$ & $\mathrm{VH}$ & $\mathrm{VH}$ & $\mathrm{VH}$ & $\mathrm{H}$ & $\mathrm{VH}$ & $\mathrm{VH}$ \\
\hline Verbena 'Florist' & $L$ & $\overline{V L}$ & $\overline{V L}$ & $\mathrm{VH}$ & $M$ & $\mathrm{VH}$ & $\mathrm{VH}$ \\
\hline Zinnia 'Scarlet' & $\mathrm{VL}$ & $\mathrm{VL}$ & $\mathrm{VL}$ & $M$ & $M$ & $\mathrm{VL}$ & $\mathrm{VL}$ \\
\hline \multicolumn{8}{|c|}{$\begin{array}{l}1 \text { (McSorley \& Frederick, J. Nematol. } 26(4 S): 773-777.1994) \text {. } \\
2 \text { Ratings: root galling }(0=\text { no galling; } V L=0.1-1.0 ; L=1.01-2.0 ; M=2.01-3.0 ; H=3.01-4.0 ; V H=4.01-5.0) ; \\
\text { reproduction }(0=\text { no eggs; } V L=1-1000 \text { eggs per plant; } L=1001-3000 ; M=3001-9000 ; H=9001-15000 ; V H>15000 ; \\
---=\text { plant not included in experiment. Only root galling ratings are available from Goff's work. }\end{array}$} \\
\hline
\end{tabular}

Table 2. Susceptibility of some annual ornamental plants to root-knot nematodes in Central Florida*.

\begin{tabular}{|c|c|c|c|}
\hline Common Name & Scientific Name & Rating & Number of Tests \\
\hline \multicolumn{4}{|c|}{ Not Infested, No Galls Found } \\
\hline Marigold, African & Tagetes sp. & 0 & 2 \\
\hline Marigold, French & Tagetes sp. & 0 & 1 \\
\hline Coreopsis & Coreopsis lanceolata & 0 & 2 \\
\hline Argemone & Argemone sp. & 0 & 1 \\
\hline Rudbeckia & Rudbeckia sp. & 0 & 1 \\
\hline Ageratum & Ageratum sp. & 0 & 1 \\
\hline Evening primrose & Oenothera erythrocephala & 0 & 1 \\
\hline Gaillardia & Gaillardia sp. & 0 & 2 \\
\hline \multicolumn{4}{|c|}{ Very Lightly Infested, with One or Few Scattered Galls } \\
\hline Michaelmas daisy & Aster tradescanti & 1 & 2 \\
\hline Lupine & Lupine sp. & 1 & 1 \\
\hline Calliopsis & Coreopsis tinctoria & 4 & 3 \\
\hline Four-o'clock & Mirabilis jalapa & 4 & 3 \\
\hline Cosmos & Cosmos bipinnatus & 4 & 3 \\
\hline Zinnia, small & Zinnia elegans & 5 & 3 \\
\hline Zinnia, giant & Zinnia elegans & 11 & 1 \\
\hline
\end{tabular}


Table 2. Susceptibility of some annual ornamental plants to root-knot nematodes in Central Florida*.

\begin{tabular}{|c|c|c|c|}
\hline Common Name & Scientific Name & Rating & Number of Tests \\
\hline Sweet alyssum & Lobularia maritima & 7 & 3 \\
\hline Torenia, blue & Torenia fournieri & 17 & 2 \\
\hline Torenia, white & Torenia sp. & 17 & 1 \\
\hline Thunbergia & Thunbergia sp. & 22 & 1 \\
\hline Blue sage & Salvia farinacea & 10 & 1 \\
\hline Scarlet sage & Salvia splendens & 20 & 1 \\
\hline Arctotis & Arctotis stoechadifolia & 14 & 3 \\
\hline Phlox, Big Drummond & Phlox drummondii & 19 & 4 \\
\hline Phlox, Dwarf & Phlox drummondii nana compacta & 31 & 1 \\
\hline Phlox, Starred & Phlox drummondii stellaris & 26 & 1 \\
\hline Statice & Limonium sinatum & 18 & 1 \\
\hline Globe amaranth & Gomphrena globosa & 25 & 1 \\
\hline Gerbera daisy & Gerbera jamesonii & 24 & 2 \\
\hline Vinca, periwinkle & Catharanthus rosea & 30 & 2 \\
\hline Stock & Matthiola sp. & 31 & 2 \\
\hline Leptosyne & Coreopsis sp. & 29 & 1 \\
\hline \multicolumn{4}{|c|}{ Lightly Infested, with a Number of Small Galls } \\
\hline Godetia & Godetia sp. & 36 & 2 \\
\hline China aster & Callistephus chinensis & 38 & 2 \\
\hline Penstemon & Penstemon sp. & 38 & 1 \\
\hline Dianthus & Dianthus sp. & 45 & 2 \\
\hline Portulaca & Portulaca sp. & 40 & 2 \\
\hline Verbena & Verbena sp. & 27 & 3 \\
\hline Lantern groundcherry & Physalis franchetii & 40 & 1 \\
\hline Perennial Sweet Pea & Lathyrus latifolius & 42 & 1 \\
\hline Liatris spicata & Liatris spicata & 44 & 1 \\
\hline Clarkia & Clarkia sp. & 23 & 2 \\
\hline Shasta daisy & Chrysanthemum maximum & 48 & 2 \\
\hline Candytuft & Iberis umbellata & 46 & 2 \\
\hline Mignonette & Reseda odorata & 50 & 1 \\
\hline Cypress vine & Ipomoea quamoclit & 50 & 1 \\
\hline Artemisia & Artemisia gemelinii & 50 & 1 \\
\hline Petunia & Petunia hybrida & 52 & 3 \\
\hline \multicolumn{4}{|c|}{ Moderately Infested, with Galls More Numerous or Larger } \\
\hline Acroclinium & Helipterum roseum & 55 & 2 \\
\hline Linaria & Linaria sp & 56 & 2 \\
\hline Poppy & Papaver sp. & 56 & 1 \\
\hline Moonflower & Ipomoea sp. & 58 & 2 \\
\hline Perennial chrysanthemum & Chrysanthemum sp. & 59 & 1 \\
\hline Nicotiana & Nicotiana alata & 59 & 1 \\
\hline Hunnemannia (Mexican tulip poppy) & Hunnemannia fumariaefolia & 60 & 1 \\
\hline Annual chrysanthemum & Chrysanthemum coronarium & 65 & 1 \\
\hline Dimorphotheca & Dimorphotheca sinuata & 66 & 2 \\
\hline English Daisy & Bellis perennis & 67 & 1 \\
\hline Scarlet Climber or Cardinal climber & Ipomoea X multifida & 71 & 2 \\
\hline California poppy & Eschscholtzia californica & 71 & 2 \\
\hline \multicolumn{4}{|c|}{ Heavily Infested: a Large Percentage of Roots with Large Galls } \\
\hline Coleus & Coleus sp. & 71 & 2 \\
\hline
\end{tabular}


Table 2. Susceptibility of some annual ornamental plants to root-knot nematodes in Central Florida*.

\begin{tabular}{|c|c|c|c|}
\hline Common Name & Scientific Name & Rating & Number of Tests \\
\hline Columbine & Aquilegia sp. & 74 & 1 \\
\hline Sunflower & Helianthus annuus & 73 & 3 \\
\hline Chinese forget-me-not & Cynoglossum sp. & 73 & 3 \\
\hline Baby's breath & Gypsophila sp. & 77 & 2 \\
\hline Gilia & Gilia sp. & 77 & 1 \\
\hline Matricaria & Matricaria sp. & 80 & 1 \\
\hline Nasturtium & Tropaeolum sp. & 85 & 2 \\
\hline Snapdragon & Antirrhinum majus & 84 & 2 \\
\hline Hollyhock & Althea rosea & 82 & 1 \\
\hline Salpiglossis & Salpiglossis sinuata & 84 & 1 \\
\hline Pansy & Viola tricolor & 87 & 2 \\
\hline Centaurea & Centaurea cyanus & 90 & 3 \\
\hline \multicolumn{4}{|c|}{ Very Heavily Infested: Practically All Roots with Many Large Galls } \\
\hline Butterfly flower & Schizanthus sp. & 87 & 1 \\
\hline Morning-glory & Ipomoea sp. & 91 & 2 \\
\hline Larkspur & Delphinium sp. & 90 & 1 \\
\hline Lobelia & Lobelia erinus & 94 & 3 \\
\hline Helichrysum & Helichrysum sp. & 96 & 2 \\
\hline Amaranthus & Amaranthus sp. & 93 & 1 \\
\hline Calendula & Calendula officinalis & 93 & 2 \\
\hline Calendula, radio & Calendula officinalis & 87 & 1 \\
\hline Balsam & Impatiens balsamina & 100 & 1 \\
\hline Blue lace flower (Didiscus) & Trachymene caerulea & 73 & 3 \\
\hline Annual Sweet Pea & Lathyrus odoratus & 96 & 2 \\
\hline Celosia & Celosia argentea & 99 & 2 \\
\hline Dolichos & Dolichos sp. & 100 & 1 \\
\hline Gourd & Cucurbita sp. & 100 & 1 \\
\hline
\end{tabular}

Table 3. Galling and reproduction of root-knot nematodes on several common cultivars of Salvia and Vinca.

\begin{tabular}{||l|c|c|c|c||}
\hline \multirow{2}{*}{ Cultivar } & \multicolumn{2}{c||}{ M. incognita } & \multicolumn{2}{c||}{ M. javanica } \\
\cline { 2 - 5 } & Galling & Reproduction & Galling & Reproduction \\
\hline \multicolumn{2}{|c|}{ Salvia (Salvia splendens) } \\
\hline Sea breeze & $\mathrm{L}$ & $\mathrm{L}$ & $\mathrm{O}$ & $\mathrm{H}$ \\
\hline Oxford blue & $\mathrm{H}$ & $\mathrm{M}$ & $\mathrm{H}$ & $\mathrm{O}$ \\
\hline Flare & $\mathrm{O}$ & $\mathrm{O}$ & $\mathrm{O}$ & $\mathrm{O}$ \\
\hline Lady in red & $\mathrm{O}$ & $\mathrm{O}$ & $\mathrm{O}$ & $\mathrm{L}$ \\
\hline Victoria & $\mathrm{O}$ & $\mathrm{O}$ & $\mathrm{L}$ & $\mathrm{O}$ \\
\hline Grape cooler & \multicolumn{2}{|c|}{ Vinca (Catharanthus roseus) } & $\mathrm{L}$ & $\mathrm{O}$ \\
\hline Blush cooler & $\mathrm{O}$ & $\mathrm{O}$ & $\mathrm{H}$ & $\mathrm{O}$ \\
\hline Little bright eyes & $\mathrm{H}$ & $\mathrm{O}$ & $\mathrm{H}$ & $\mathrm{O}$ \\
\hline \hline
\end{tabular}


Table 3. Galling and reproduction of root-knot nematodes on several common cultivars of Salvia and Vinca.

\begin{tabular}{||l|c|c|c|c||}
\hline \multirow{2}{*}{ Cultivar } & \multicolumn{2}{c|}{ M. incognita } & \multicolumn{2}{c||}{ M. javanica } \\
\cline { 2 - 5 } & Galling & Reproduction & Galling & Reproduction \\
\hline Little mixed colors & $\mathrm{H}$ & $\mathrm{O}$ & $\mathrm{H}$ & $\mathrm{O}$ \\
\hline Peppermint cooler & $\mathrm{M}$ & $\mathrm{O}$ & $\mathrm{M}$ \\
\hline $\mathrm{O}=$ No galling or reproduction \\
$\mathrm{M}=$ Moderate galling or reproduction
\end{tabular}

Table 4. Marigold species and varieties differ in their usefulness in managing root-knot nematodes. ${ }^{1}$

\begin{tabular}{|c|c|c|c|c|}
\hline $\begin{array}{l}\text { Marigold Species } \\
\text { and Varieties }\end{array}$ & M. incognita & M. arenaria & M. hapla & M. javanica \\
\hline \multicolumn{5}{|c|}{ American marigolds, Tagetes erecta } \\
\hline 'Alaska' & $\mathrm{G}^{*}$ & $\mathrm{G}$ & $\mathrm{M}$ & $\mathrm{G}$ \\
\hline 'Cracker Jack' & $\mathrm{G}$ & $\mathrm{G}$ & $\mathrm{G}$ & M \\
\hline 'Diamond Jubilee' & G & M & $P$ & G \\
\hline 'Flor de Muerto' & $\mathrm{G}$ & $\mathrm{G}$ & $\mathrm{G}$ & $\mathrm{M}$ \\
\hline 'Toreador' & $\mathrm{G}$ & $\mathrm{G}$ & $\mathrm{P}$ & $\mathrm{G}$ \\
\hline \multicolumn{5}{|c|}{ Triploid hybrid marigold, Tagetes erecta X T. patula } \\
\hline 'Polynema' & $\mathrm{G}$ & $P$ & M & M \\
\hline 'Red Nugget' & $\mathrm{M}$ & $\mathrm{G}$ & M & $\mathrm{G}$ \\
\hline \multicolumn{5}{|c|}{ French marigolds, Tagetes patula } \\
\hline 'Bolero' & $\mathrm{M}$ & $\mathrm{M}$ & $\mathrm{P}$ & $\mathrm{G}$ \\
\hline 'Bonita Mixed' & $\mathrm{G}$ & $\mathrm{G}$ & G & M \\
\hline 'Goldie' & $\mathrm{G}$ & $\mathrm{G}$ & $\mathrm{P}$ & $\mathrm{G}$ \\
\hline 'Gypsy Sunshine' & G & $\mathrm{G}$ & G & $P$ \\
\hline 'Petite' & $\mathrm{G}$ & $\mathrm{G}$ & $\mathrm{G}$ & $\mathrm{G}$ \\
\hline 'Petite Harmony' & $\mathrm{G}$ & $\mathrm{G}$ & $\mathrm{P}$ & $\mathrm{G}$ \\
\hline 'Scarlet Sophie' & G & G & G & $\mathrm{P}$ \\
\hline 'Single Gold' & G & G & G & $P$ \\
\hline 'Tangerine' & $\mathrm{G}$ & G & M & G \\
\hline \multicolumn{5}{|c|}{ Signet marigold, Tagetes signata pumila } \\
\hline 'Golden Gem' & $P$ & $P$ & $P$ & $P$ \\
\hline 'Tangerine Gem' & $P$ & $P$ & $P$ & $P$ \\
\hline \multicolumn{5}{|c|}{$\begin{array}{l}1 \text { Data from D. A. Rickard \& A. W. Dupree, Jr. 1978. The "Tagetes effect" on four Meloidogyne spp. on tomato in the } \\
\text { greenhouse, } 1977 \text {. Fungicide \& Nematicide Tests } 33: 208 \text { and A. T. Ploey. 1999. Greenhouse studies on the effect of } \\
\text { Marigold. Journal of Nematology 31:62-69. } \\
\text { * } G=\text { Good, M = Moderate, P = Poor }\end{array}$} \\
\hline
\end{tabular}

